\title{
MEDICAL IMPACTS OF ANTHROPOMETRIC RECORDS
}

\author{
S. S. Adebisi
}

Department of Human Anatomy, Faculty of Medicine, Ahmadu Bello University, Zaria, Nigeria Reprint requests to: Dr. S. S. Adebisi, Department of Human Anatomy, Faculty of Medicine, Ahmadu Bello University, Zaria, Nigeria. E-mail: sam adebisi@yahoo.com

\begin{abstract}
Anthropology is now one of the inter-disciplinary scientific fields that is gaining much attention in forensic, socio-cultural, industrial and bio-medical applications. There is a need for a better awareness of some of the impacts - past and present, in the medical practice, of the records that were obtained by workers in this field in view of their proper applications. and future reference. Compilation of anthropometric works and records was conducted to evaluate the previous and current implications with the aim to highlight the importance of this seemingly old but yet evolving and dynamic subject and to elucidate its usefulness. However, despite the arduous efforts to get reliable data from anthropometric investigations, errors had most times characterized the concluding postulations of many workers in this field in the past, creating skepticism. But with better attention being given to the exercise, possible improvement in the methodology of the study with resultant authentic records and more reliable conclusion is anticipated.
\end{abstract}

Keywords: Anthropometry, records, implications

\begin{abstract}
Résumé
L' anthropologie a acquìs droit de cité en tant que domaine scientifique interdisciplinaire qui s'impose dans les applications légales, socio-culturelles et bio-médicales. Ainsi, il est nécessaire de bien comprendre l'impact-passé et présent dans la pratique médicale_sur les registres que ceux qui travaillent dans le domaine ont obtenus en vue de leurs applications appropriées, et pour des références futures. Les travaux anthropométriques et les registres ont été compilés pour évaluer les implications antérieures et celles qui sont en cours, afin de mettre en vedette I' importance de cette discipline apparemment vieille mais qui continue ā se dévélopper et ā se dynamiser et de faire le point sur son utilité. Cependant, malgré les efforts ardus déployés pour obtenir des données sûres qu'on peut croire sur les investigations anthropométriques, des erreurs ont toujours dominé, dans le passé, les résultats de beaucoup de recherches dans le domaine, créant ainsi un doute. Mais, si on accorde plus de sérieux ā l' exercise, on anticipe une amélioration en méthodologie de recherche quand on a des registres authentiques et une conclusion plus fiable.
\end{abstract}

Mots-clés: Anthropométr les registres, implications

\section{Introduction}

Anthropometry (Greek $\alpha v \theta \rho \omega \pi \circ \varsigma$, man, and $\mu \varepsilon \tau \rho o v$, measure), literally meaning measurement of humans, refers to measurement of living humans for the purposes of understanding human physical variation. ${ }^{1}$ Anthropometry plays an important role in industrial design, clothing design, ergonomics, and architecture, where statistical data about the distribution of body dimensions in the population are used to optimize products. Changes in life styles, nutrition and ethnic composition of populations lead to changes in distribution of body dimensions and require regular updating of anthropometric data. ${ }^{1}$ 
The French savant, Alphonse Bertillon gave this name in 1883 to a system of identification depending on the unchanging character of certain measurements of parts of the human frame. He found by patient inquiry that several physical features and the dimensions of certain bones or bony structures in the body remain practically constant during adult life. He concluded from this that when these measurements were made and recorded systematically every single individual would be found to be perfectly distinguishable from others. The system was soon adapted to police methods, as the immense value of being able to fix a person's identity was fully realized, both in preventing false personation and in bringing home to any one charged with an offense his responsibility for previous wrongdoing. 'Bertillonage,' as it was then called, became widely popular, and after its introduction into France in 1883, where it was soon credited with highly gratifying results, was applied to the administration of justice in most civilized countries. England followed tardily, and it was not until 1894 that an investigation of the methods used and results obtained was made by a special committee sent to Paris for the purpose. It reported favorably, especially on the use of the measurements for primary classification, but recommended also the adoption in part of a system of finger prints as suggested by Francis Galton, and already practiced in Bengal. $^{2}$
This systematic collection and correlation of measurements of the human body, now one of the principal techniques of physical anthropology, the discipline originated in the 19th century, when early studies of human biological and cultural evolution stimulated an interest in the systematic description of populations both living and extinct. In the latter part of the 19th century, anthropometric data were applied, often subjectively, by social scientists attempting to support theories associating biological race with levels of cultural and intellectual development. The Italian psychiatrist and sociologist Cesare Lombroso, seeking physical evidence of the so-called criminal type, used the methods of anthropometry to examine and categorize prison inmates. $^{3}$

The present work is a narrative outline of some previous and present efforts in anthropometric studies, and their past, present and anticipated implications in our world.

\section{Materials and Methods}

Analyzed anthropometric data were collated from the works of the following authors ${ }^{4-15}$ and presented as follows to show some of the references in this report and which possibly may be among those commonly mentioned by other workers.

Table 1. The comparative craniometric values $(\mathrm{mm})$ of the skull in some races (Shuklar AP et al., 1973; Adebisi, SS. 2003)

\begin{tabular}{|c|c|c|c|c|c|c|c|c|c|c|c|c|c|}
\hline Authors & Year & Race & $\mathrm{CL}$ & $\mathrm{CB}$ & $\mathrm{NH}$ & NB & $\mathrm{OH}$ & OB & $\mathrm{FH}$ & $\mathrm{Cl}$ & OI & $\mathrm{NI}$ & $\mathrm{FI}$ \\
\hline Turners & 1900 & White & 173.0 & 126.1 & - & - & - & - & - & 72.9 & 86.3 & - & - \\
\hline Tildesky & 1920 & White & 175.5 & 132.3 & - & - & - & - & - & 78.5 & - & 49.7 & - \\
\hline $\begin{array}{l}\text { Morant \& } \\
\text { Woo }\end{array}$ & 1912 & White & 178.6 & 128.5 & - & - & - & - & - & 72.0 & - & 52.2 & - \\
\hline Singh et al & 1973 & Indian & 176.2 & 127.5 & 48.6 & 24.7 & 32.8 & 32.7 & 63.6 & 72.0 & 86.6 & 52.2 & 51.9 \\
\hline \multirow[t]{3}{*}{ Adebisi } & 2003 & Black & & & & & & & & & & & \\
\hline & & male & 208.0 & 152.0 & 58.8 & 47.3 & 42.0 & 39.3 & 128.0 & 76.7 & 93.7 & 72.0 & 97.0 \\
\hline & & female & 202.0 & 151.0 & 46.5 & 34.2 & 34.7 & 37.0 & 118.0 & 73.8 & 69.3 & 70.3 & 87.7 \\
\hline
\end{tabular}

CL: Cranial length; $\mathrm{CB}$ : cranial breadth; $\mathrm{NH}$ : nasal height; NB: nasal breadth; $\mathrm{OH}$ : orbital height; OB: orbital breadth; FH: facial height; $\mathrm{Cl}$ : cranial index; OI: orbital index; $\mathrm{NI}$ : nasal index; $\mathrm{FI}$ : facial index

Table 2. The mean comparative diameter $(\mathrm{mm})$ of femoral head in some races (Singh, SP et al., 1986)

\begin{tabular}{lllll}
\hline Author & Year & Race & Male & Female \\
\hline Holby & 1918 & Caucasians & 48.80 & 41.75 \\
Lafgren & 1956 & Whites (Finns) & 48.00 & 44.00 \\
Thieme & 1957 & African American & 47.17 & 41.52 \\
Khan & 1959 & Indians & 48.00 & 41.00 \\
Singh et al & 1971 & Indians & 44.20 & 39.80 \\
Singh et al & 1983 & Nigerians & 52.02 & 46.80 \\
\hline
\end{tabular}




\section{Results (Tables $1-3)$}

This brief survey of some of the previous anthropometric data indicate that while various discrepancies exist in the configuration of the skull in the Caucasians and Negroes, that is, Africans, the cranial indices $(\mathrm{Cl})$ were relatively within a close range of 70s; the Negroes have relatively higher values in other features of the bone (Table 1). The same observation was applicable to the femoral head dimensions in Table 2, with relatively higher figures in the Negroes. Such observations are usually contributory factors to the basis of the discriminant categorization of human race and class.

Table 3. Comparison (in \%) of the various identification points (IP) and de-marking points (DP) of the ulnae in Indians (Shamer S. et al., 1974)

\begin{tabular}{|c|c|c|c|c|c|c|c|c|}
\hline \multirow[t]{3}{*}{ Measurements } & \multicolumn{4}{|l|}{ Right } & \multicolumn{4}{|l|}{ Left } \\
\hline & \multicolumn{2}{|l|}{ Male } & \multicolumn{2}{|c|}{ Female } & \multicolumn{2}{|c|}{ Male } & \multicolumn{2}{|c|}{ Female } \\
\hline & IP & $\mathrm{DP}$ & IP & $\mathrm{DP}$ & IP & DP & $\mathrm{IP}$ & $\mathrm{DP}$ \\
\hline Weight & 38 & 36 & 79 & 40 & 48 & 29 & 77 & 23 \\
\hline Length & 36 & 12 & 62 & 0 & 26 & 9 & 70 & 33 \\
\hline Distal width & 39 & 5 & 3 & 3 & 32 & 1 & 3 & 0 \\
\hline $\begin{array}{l}\text { Mid-shaft } \\
\text { circumference }\end{array}$ & 32 & 3 & 45 & 0 & 25 & 1 & 45 & 15 \\
\hline
\end{tabular}

\section{Discussion}

\section{Trends and techniques in anthropometry}

The simplest anthropometric measurements included the ratio of the breadth to the length of the skull, that is, the 'cephalic index'; that of the width to the length of the nose; the proportion of the upper arm to the lower arm, length, weight, mid-shaft circumference, angularity in the bones configurations and so on. These measurements could be made with such familiar pieces of equipment as weight gauge, meter-sticks, calipers, and measuring tapes. By selecting reliable measuring points, or landmarks, on the body, and standardizing the measuring techniques used, measurements could be made with great accuracy. 4

The masses of data acquired from such investigations were used by physical anthropologists in the 19th and early 20th centuries to try to characterize various racial, ethnic, and national groups in terms of those bodily features peculiar to or typical of them. In addition to its scholarly functions, anthropometry also has commercial applications. Anthropometric data have been used by industrial researchers in the design of clothing, especially military uniforms, and in the engineering of, for example, automobile seats, airplane cockpits, and space capsules. In the 20th century, the application of anthropometry to the study of racial types was replaced by more sophisticated techniques for evaluating racial differences. Anthropometry continued to be a valuable technique, however, gaining an important role in paleo-anthropology, the study of human origins and evolution through fossil remains. $^{15}$

\section{Craniometry and anthropology}

In particular, craniometry, the measurement of the skull and facial structure, also a development of the 19th century, assumed new importance with the discoveries in the 1970s and ' 80 s of human and prehuman fossils greatly predating any such previous finds. Craniometric studies of prehistoric skull and face bones have enabled anthropologists to trace the gradual changes that occurred in the size and shape of the human head as it enlarged to accommodate increased brain volume; as a result, craniometry and other anthropometric techniques led to a major reevaluation of prevailing theories that the adoption of an erect posture and the enlargement of the brain occurred simultaneously in human development.

Craniometry, the technique of measuring the bones of the skull, was once intensively practiced in anthropology/ethnology. It is distinct from phrenology, the study of personality and character, and physiognomy, the study of facial features. However, these fields have all claimed the ability to predict traits or intelligence. They were once intensively practiced in anthropology, in particular in physical anthropology in the 19th century. Swedish professor of anatomy Anders Retzius (1796-1860) first used the cephalic index in physical anthropology to classify ancient human remains found in Europe. He classified brains into three main categories, "dolichocephalic" (from the ancient Greek kephalê, head, and dolikhos, long and thin), "brachycephalic" (short and broad) and "mesocephalic" (intermediate length and width). ${ }^{15}$

Theories attempting to scientifically justify the segregation of society based on race became popular during the days of Reitzius. One of its prominent 
figure being Georges Vacher de Lapouge (18541936), who adopted Retzius terms divided humanity into various, hierarchized, different races. Such attempts to relate the form of the skull to a particular character or intelligence are today unanimously denounced by the scientific community as pseudoscience, while historians study the influence and caution science provided for racially divisive ideologies in the late 19th and early 20th century, at the height of the New Imperialism period. On the other hand, craniometry and the study of skeletons were used to demonstrate Charles Darwin's theory of evolution first expressed in his book: The Origin of Species in $1859 .^{15}$

Pieter Camper invented the facial angle, a measure meant to determine intelligence among various human races. According to this technique, a facial angle was formed by drawing two lines: one horizontally from the nostril to the ear; and the other perpendicularly from the advancing part of the upper jawbone to the most prominent part of the forehead. Camper claimed that antique statues presented an angle of $90^{\circ}$, Europeans of $80^{\circ}$, Black people of $70^{\circ}$ and the orangutan of $58^{\circ}$, thus displaying a hierarchic view of mankind, based on a decadent conception of history. It has been explained that the measurements were first made with a view to elucidating the comparison of the skulls of men with those of other animals. This wide comparison constitutes the first subdivision of craniometric studies. It is further remarkable that among the first measurements employed angular determinations occur, and indeed the name of Camper is chiefly perpetuated in anthropological literature by the facial angle invented by that artist-anatomist. Camper's work followed the lines of 18th century scientific theories, where his measurements of facial angle were used to liken the skulls of non-Europeans to those of apes. ${ }^{16}$

The work of Earnst Haeckel between 1834 -1919 became famous for its now outdated 'recapitulation theory' which stated that each individual mirrored the evolution of the whole species during his life time. Such researches on skulls and skeletons had helped to liberate the 19th century Europe from its ethnocentrism biases. In particular, the discovery of the 'Java Man' by Eugene Dubois in 1858-1940, which was the first specimen of Homo erectus to be displayed in 1891 in Trinil, Indonesia demonstrated mankind's deep ancestry outside Europe. ${ }^{16}$

Samuel George Morton (1799-1851), one of the inspirator of physical anthropology, collected hundreds of human skulls from all over the world and started trying to find a way to classify them according to some logical criteria. Influenced by the common theories of his time, he claimed that he could judge the intellectual capacity of a race by the cranial capacity (the measure of the volume of the interior of the skull). A large skull meant a large brain and high intellectual capacity, and a small skull indicated a small brain and decreased intellectual capacity. By studying these skulls he decided at what point Caucasians stopped being Caucasians, and at what point Negroes began. Morton had many skulls from ancient Egypt, and concluded that the ancient Egyptians were not African, but white. His two major monographs were the Crania Americana, An Inquiry into the Distinctive Characteristics of the Aboriginal Race of America (1839) and Crania Aegyptiaca (1844). In Crania Americana, he claimed that the mean cranial capacity of the skulls of Whites was (1425 $\left.\mathrm{cm}^{3}\right)$, while that of Blacks was $\left(1278 \mathrm{~cm}^{3}\right)$. Based on the measurement of 144 skulls of Native Americans, he reported a figure of $\left(1344 \mathrm{~cm}^{3}\right)$. 17

Craniometry was also used in phrenology, which purported to determine character, personality traits, and criminality on the basis of the shape of the head and thus of the skull. At the turn of the 19th century, Franz Joseph Gall (1758-1822) developed 'cranioscopy' (ancient Greek «cranium»: skull, "scopos»: vision), a method to determine the personality and development of mental and moral faculties on the basis of the external shape of the skull. Cranioscopy was later renamed phrenology (phrenos»: mind, "logos»: study) by his student Johann Spurzheim (1776-1832), who wrote extensively on the 'Drs. Gall and Spurzheim's physiognomical System' ${ }^{17}$ Physiognomy claimed a correlation between physical features (especially facial features) and character traits. It was made famous by Cesare Lombroso (1835-1909), the founder of anthropological criminology, who claimed to be able to scientifically identify links between the nature of a crime and the personality or physical appearance of the offender. The originator of the concept of a "born criminal" and arguing in favor of biological determinism, Lombroso tried to recognize criminals by measures of their body. He concluded that skull and facial features were clues to genetic criminality, these features could be measured with craniometers and calipers with the results developed into quantitative research. A few of the 14 identified traits of a criminal included large jaws, forward projection of jaw, low sloping forehead; high cheekbones, flattened or upturned nose; handleshaped ears; hawk-like noses or fleshy lips; hard shifty eyes, scanty beard or baldness; insensitivity to pain, long arms.

Anthropometrics was first used in the 19th and early 20th century in criminalistics, to identify criminals by facial characteristics. ${ }^{18}$ Francis Galton was a key contributor as well, and it was in showing the redundancy of Bertillon's measurements that he developed the statistical concept of correlation. Bertillon's goal was to use anthropometry as a way of identifying recidivists-what we would today call 'repeat-offense' criminals. Previously, police could 
only record general descriptions and names, and criminals were fond of using alternative identities. As such, it was a difficult job to identify whether or not certain individuals arrested were 'first offenders' or life-long criminals. ${ }^{18}$

Craniometry is also employed in the measurement of cranial features in order to classify people according to race, criminal temperament, intelligence, and so forth. The underlying assumption of craniometry is that skull size and shape determine brain size which determines such things as intelligence and capacity for moral behavior. Empirical evidence for this assumption is not very strong. This fact has not hindered small-headed people from claiming they are members of a superior race or gender because the head size of their racial or gender group is larger on average than the head size of some other racial or gender group. ${ }^{11,16}$ As members of superior races and gender, these smallheaded people reason that they, too, must be superior to all members of races inferior to their own and of all members of the other gender. In logic, this is called the fallacy of division: reasoning that what is true of the whole or group must also be true of the parts or members of the group. ${ }^{18}$

In the 19th century, the British used craniometry to justify its racist policies toward the Irish and black Africans, whom the British considered to be inferior races. Irish skulls were said to have the shape of CroMagnon men and were akin to that of apes, proof of their inferiority along with black Africans. In France, Paul Broca demonstrated that women are inferior to men because of their smaller crania. He argued against higher education for women because their small brains couldn't handle the demands. ${ }^{16}$

In the 20th century, the Nazis used craniometry and anthropometry to distinguish Aryans from nonAryans. The Belgians used these pseudo-sciences, among other things, to distinguish Hutus from Tutsis in Rwanda. In the 1930s the Belgians required everybody in Rwanda to start carrying an identity card classifying themselves as Hutu or Tutsi, thereby markedly increasing the ethnic distinction that had already existed. Forensic anthropologists believe that by taking some 90 measurements of a skull they can correctly assign its owner's continent of origin broadly speaking, its race, though many anthropologists prefer not to use that term - with 80 percent accuracy. 17

\section{Extra-cranial anthropometry}

In addition to the skull and pelvis, the femur is another bone of great anthropological and medicolegal importance. Anatomists are often called upon to give expertise advice on skeletal remains in such controversial instances. ${ }^{20}$ The human femur being the longest and most robust bone in the skeleton especially for its role in bipedal posture and gait, the shaft angulations plus the anatomical features of the pelvis form a morphological pattern which is evidently needed for erect posture and bi-pedal gait. The variation in the obliquity of the shaft of the femur (bicondylar angle) forms the basis of study and de-marking points to ascertaining age, sex, race or hominid character. This is also crucial to physiotherapists, orthopaedic surgeons and others. ${ }^{14}$

During the early 20th century, anthropometry was used extensively in the United States and Europe in attempt of segregation between races of man, and it was often employed to show ways in which races were inferior to others. The wide application of intelligence testing also became incorporated into a general anthropometric approach, and many forms of anthropometry were used for the advocacy of eugenics policies. During the 1920s and 1930s, though, members of the school of cultural anthropology of Franz Boas also began to use anthropometric approaches to discredit the concept of fixed biological race. Anthropometric approaches to these types of problems became abandoned in the years after the Holocaust in Nazi Germany, which also famously relied on anthropometric measurements to distinguish Aryans from Jews. This school of physical anthropology generally went into decline during the 1940s. During the 1940s anthropometry was used by William Sheldon when evaluating his somatotypes, according to which characteristics of the body can be translated into characteristics of the mind. Inspired by Cesare Lombroso's criminal anthropology, he believed that criminality could be predicted according to body type. This use of anthropometry is today outdated. ${ }^{19}$

\section{Current strides in anthropometry}

Anthropometric studies are today conducted for numerous different purposes. Academic anthropologists investigate the evolutionary significance of differences in body proportion between populations whose ancestors lived in different environmental settings. Human populations exhibit similar climatic variation patterns to other large-bodied mammals, following Bergmann's rule, which states that individuals in cold climates will tend to be larger than ones in warm climates, and Allen's rule, which states that individuals in cold climates will tend to have shorter, stubbier limbs than those in warm climates. ${ }^{17}$ On a micro-evolutionary level, anthropologists use anthropometric variation to reconstruct small-scale population history. For instance, John Relethford's studies of early twentieth-century anthropometric data from Ireland show that the geographical attuning of body proportions still exhibits traces of the invasions by the English and Norse centuries ago. 19 
Outside academia, scientists working for private companies and government agencies conduct anthropometric studies to determine what range of sizes in clothing and other items need to be manufactured. A basically anthropometric division of body types into the categories endomorphic, ectomorphic and mesomorphic derived from Sheldon's somatotype theories is today popular among people doing weight training. Over 40 anthropometric surveys of US Military personnel were conmducted between 1945 and 1988, including the 1988 Army Anthropometric Survey (ANSUR) of men and women with its 240 measures. Statistical data from these surveys encompassed over 75000 individuals. $^{20}$

Today people are performing anthropometry with three-dimensional scanners. The subject has a three-dimensional scan taken of their body, and the anthropometrist extracts measurements from the scan rather than directly from the individual. This is beneficial for the anthropometrist in that they can use this scan to extract any measurement at any time and the individual does not have to wait for each measurement to be taken separately. ${ }^{3}$

A global collaborative study to examine the uses of three-dimensional scanners for health care was launched in March 2007. The body benchmark study will investigate the use of three-dimensional scanners to calculate volumes and segmental volumes of an individual body scan. The aim is to establish whether the body volume index has the potential to be used as a long-term computer based anthropometric measurement for health care. ${ }^{3}$

\section{References}

1. http://en.wikipedia.org/wiki/Anthropometry April 20, 2007.

2. Pierre-André T. La couleur et le sang - Doctrines racistes à la française "Colour and Blood doctrines à la française", Paris, Mille et une nuits; 2002; P. 203.

3. Anthropometry. In: Encyclopædia Britannica. April 4, 2007.

4. Holtby JRD. Some indices and measurements of the modern femur. J Anat. 1918;52:363-382.

5. Khan MA. In: Modi MJ (ed). Textbook of medical jurisprudence and toxicology. Tripathi Press, Bombay, 1969; P.80.

6. Lofgren L. Some anthropometric anatomical measurements of the femur of Finns from the view poits of surgery. Acta Chir Scand. 1956;110:477-484.

7. Singh S, Singh SP. Weight of the femur-a useful measurement for identification of sex. Acta Anat (Basel). 1974;87:141-145.

8. Singh S, Jit I, Singh SP. Identification of sex from the skeletal remains. Bull Inst. Med. Sci. 1972;3:65-75.

9. Thieme FP. Sex in Negro skeleton. J Forensic Med. 1957;4:72-81.

10. Shukla AP, Singh SP, Shamer S. Morphological and Metrical Analysis of Indian Crania. 1973;12:492-498.

11. Morant GM, Woo TL. A preliminary classification of Indian and Asiatic races. Biometrika. 1932;24:108-134.

12. Turner W. Contributions to craniology of population of India. Tran Roy Soc Ed 1900; 40: 59-101.

13. Adebisi SS. Sex identification from the skull of the Hausa/Fulani in Northern Nigeria. Ann Afr Med. 2003;2:22-26.

14. Singh SP, Ekandem GJ, Ani OEO. Identification of sex from head of the femur-demarking points for Calabar, Cross River State. West African Journal of Anatomy. 1986;1:16-27.

15. Gould SJ. American Polygeny and craniometry before Darwin: blacks and Indians as separate, inferior species. In: Harding, Racial Economy of Science, 1981; 84-115.

16. Bolt C. Victorian attitudes to race. Routledge and Kegan Paul, London, 1971; 212.

17. Zack ZC. Rushton's defenders and their hasty rejection of the null hypothesis. J Black Psychol. 1994;20:325-333.

18. Singer P. Practical ethics. Cambridge University Press, Cambridge, 199; 145.

19. Wade N. A new look at old data may discredit a theory on race. New York Times, October 8; 2002. 